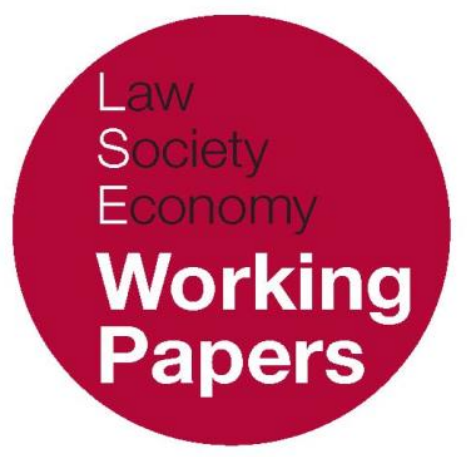

\title{
Beyond the Post-Sovereign State? \\ The Past, Present and Future of Constitutional Pluralism
}

Forthcoming in Cambridge Yearbook of European Legal Studies

\author{
Michael A. Wilkinson
}

LSE Law, Society and Economy Working Papers 9/2019 London School of Economics and Political Science

Law Department

This paper can be downloaded without charge from LSE Law, Society and Economy Working Papers at: www.lse.ac.uk/collections/law/wps/wps.htm and the Social Sciences Research Network electronic library at: https://ssrn.com/abstract=3405418.

C Mike Wilkinson. Users may download and/or print one copy to facilitate their private study or for non-commercial research. Users may not engage in further distribution of this material or use it for any profit-making activities or any other form of commercial gain. 


\title{
Beyond the Post-Sovereign State?
}

\section{The Past, Present and Future of Constitutional Pluralism}

\author{
Michael A. Wilkinson ${ }^{*}$
}

Commented [U(1]: Please let me know whether you'd like to change your title and/or add any acknowledgments in the note below.

\begin{abstract}
Constitutional pluralism is a theory for the post-sovereign European state. This state-type can only be made sense of historically, emerging out of postwar European reconstruction through the repression of popular sovereignty and restraining of democracy associated with various forms of depoliticisation, including the project of European integration. It starts to become unsettled at Maastricht, just as Neil MacCormick lays the ground for its theoretical development with his Lecture, 'Beyond the Sovereign State'. This unsettling evolves from a series of irritants into a full-blown crisis in the recent decade, with sovereignty claims returning both from the bottom-up and the top-down, to the extent that we can legitimately ask whether we are now moving 'beyond the post-sovereign state'? This is all missed in a constitutional pluralist literature that evades material issues of democracy and political economy.
\end{abstract}

Keywords: Constitutional pluralism, Sovereignty, Post-Sovereignty, Democracy, Political Economy

* Associate Professor of Law, London School of Economics. I would like to thank Cormac Mac Amhlaigh and Kenneth Armstrong for comments on earlier drafts. 


\section{INTRODUCTION}

Constitutional pluralism is a theory, or set of theories, for the post-sovereign European state and state-sytem. Its basic theoretical move is twofold. First, the concept of sovereignty - understood as ultimate political authority - is folded into constitutional authority, into the constitution itself and thereby into its authoritative interpreters, particularly, if not exclusively, constitutional courts. Second, constitutional authority is then presented as quasi-federal or compound in nature, a feature of a multi-layered constitutional system comprising the domestic constitution and a European constitution (and their respective authoritative interpreters).

In the article that launched a thousand more, Neil MacCormick was quite explicit about his own 'post-sovereign' agenda. ${ }^{1}$ Based on the 1992 Chorley Lecture, in the heat of the Maastricht debates, the article, entitled 'Beyond the Sovereign State', begins by outlining the 'widespread view' that sovereignty is 'mightily important', and then offers a contrasting perspective; that the era of the sovereign state is over:

A different view would be that sovereignty and sovereign states, and the inexorable linkage of law with sovereignty and the state, have been but the passing phenomena of a few centuries, that their passing is by no means regrettable, and that current developments in Europe exhibit the possibility of going beyond all that. On this view, our passing beyond the sovereign state is to be considered a good thing, an entirely welcome development in the history of legal and political ideas. This will be the view stated in the present lecture. ${ }^{2}$

MacCormick's goal, as he later put it, was to defend the 'coexistence of two entities', 'the states of Europe, now not-fully-sovereign states, and the European Union, still a nonsovereign Union'. ${ }^{3}$ But what begins as aspirational and normative, is, by the end of the Lecture, presented as a fait accompli. He concludes, emphatically, that 'beyond the sovereign state is where we are now'. ${ }^{4}$

That, of course, was a quarter of a century ago. Precisely where we are in the current moment is questionable. But we are not, or no longer, beyond the sovereign state. We may, however, be beyond the post-sovereign state. Or so it will be argued.

The argument in brief is that MacCormick erred in his diagnosis, basing it on a reductive view of sovereignty in line with his legal positivism. But he was wrong in a revealing way. A 'post-sovereign ideal-type' did emerge out of postwar reconstruction, paradigmatically in West Germany. Sovereignty, however, was not transcended as the label might suggest; it was folded in, or repressed. ${ }^{5}$ This is a complex phenomenon, comprising not only formal, institutional developments - domestically and transnationally - aimed at

${ }^{1}$ N MacCormick, 'Beyond the Sovereign State’ (1993) 56:1 Modern Law Review 1.

${ }^{2}$ Ibid at 1.

${ }^{3}$ MacCormick, Questioning Sovereignty: Law, State and Nation in the European Commonvealth (OUP, 2002) 142.

${ }^{4}$ Note 1 , above at 18 .

${ }^{5}$ See M Wilkinson, 'The Reconstitution of Postwar Europe: Liberal Excesses, Democratic Deficiencies' in M

Dowdle and M Wilkinson (eds.) Constitutionalism Beyond Liberalism (CUP, 2017) 38. 
constraining democracy, but also informal socio-economic, political and even cultural changes relating to ideas about the limits of self-government and democratic control over the economy.

Postwar reconstruction provides the conditions for a deracinated constitutionalism, disconnected from popular sovereignty. These are propitious conditions for the development of European constitutionalism and the constitutional pluralism that followed in its wake. ${ }^{6}$ But the post-sovereign dynamic reaches a turning point in the Maastricht era. Just as MacCormick identifies it, the ground for constitutional pluralism becomes increasingly unstable: functional and systemic differentiation between the domestic and EU constitution becomes harder to sustain, German reunification places the question of popular sovereignty squarely back on the table, the German Constitutional Court steps up its own quest for constitutional sovereignty vis-à-vis the ECJ, the democratic deficit of the EU becomes more acute, and with the rise of various Eurosceptic political movements, nationalism starts to reassert itself as a political and social phenomenon. As the postsovereign state increasingly resembles a post-democratic state, the permissive consensus on European integration comes to an end.

What begins at Maastricht as a set of mere irritants grows through the Euro-crisis phase into a full-blown crisis of post-sovereignty and of constitutional pluralism. Sovereignty claims now re-emerge both 'from below', in regard to the so-called 'populist' surge in the nation-state (in the core of Europe as well as in the periphery) and 'from above', in regard to a European Union that is increasingly exercising emergency politics of its own, in response to the various crises. The recent Brexit referendum potentially represents the moment of rupture from the postwar project of post-sovereignty, although it is too early to say where it will lead.

Due to inequalities within the European Union among the Member States, the present conjuncture is asymmetric. The EU comes to resemble a hegemonic federation, in which there is both material and ideological domination: in the Euro area especially, one country or bloc of countries increasingly exercises de facto sovereignty over others. ${ }^{7}$ The crisis of postsovereignty does not therefore necessarily signal the return of classical state sovereignty (either domestically or upscaled to the $\mathrm{EU}$ ); the idea of sovereignty is highly distorted, severed from any credible connection with democracy and sovereign equality. This is all missed in constitutional theory that fails to attend to questions of political economy and state transformation.

The paper proceeds in five steps. First, it argues that constitutional pluralism, as it emerges out of the work of Neil MacCormick, represents the pluralization of ultimate legal authority through the repression of political sovereignty. Although a consequence of narrow (positivist) methodological premises, this cannot be straightforwardly dismissed, because, as argued in a second stage, the repression is a real and significant feature of the postwar constitutional settlement. It will be argued, third, that post-sovereignty becomes unsettled at Maastricht as sovereignty claims start to return and that it appears increasingly

${ }^{6}$ The repression of the concept of sovereignty in fact suggests the EU is in that respect a classic federation, a third type besides the loose confederation of sovereign states and the federal state. See e.g. O Beaud, Theorie de la Federation (Presses Universitaires de France, 2009).

${ }^{7}$ See e.g. U Beck, German Europe (Polity Press, 2013). 
untenable during the Euro-crisis phase as existential challenges mount, albeit without any conclusive rupture. In a fourth step, the paper returns to MacCormick, to examine why all of this is evaded in much of the constitutional pluralist literature. I will conclude with a final irony: the survival of constitutional plurality in Europe may now require the reclaiming of sovereignty by reclaiming the idea of ultimate democratic political authority.

\section{QUESTIONING QUESTIONING SOVEREIGNTY: EXPOSING THE TWOFOLD THEORETICAL MOVE OF CONSTITUTIONAL PLURALISM}

The repression of sovereignty in the constitutional pluralist imagination is reflected in two complementary moves: first the concept of sovereignty is folded into constitutional authority and often into legality - constitutionalism - and second, it is systematised through the co-existence of two or more sets of juridical claims to ultimate legal authority constitutional pluralism. ${ }^{8}$ Although conceptually the first, constitutionalist move, is prior, the second is more explicit in the literature, and so it makes sense to begin there.

\section{A. Constitutional Pluralism}

Within the context of European integration, where it is most often articulated, constitutional pluralism amounts to the claim that there are two sets of final interpretative jurisdictions, domestic and European, without any ultimate arbiter:

It is for the European Court of Justice to interpret in the last resort and in a finally authoritative way the norms of Community law. But equally, it must be for the highest constitutional tribunal of each Member State to interpret its constitutional and other norms, and hence to interpret the interaction of the validity of EC law with higher level norms of validity in the given state system. Interpretative competencecompetence is a feature of the highest tribunal of any normative system. ${ }^{9}$

In the early stages of integration, with two legal orders functionally and systemically differentiated, the presumption was that the authority of each could co-exist without friction. But once the ECJ had presented its own legal order as effectively constitutional in form, through the doctrines of direct effect and primacy, the potential for conflict emerged, as evidenced most famously in Internationale Handelsgesselschaft and the Solange

\footnotetext{
${ }^{8}$ For a recent restatement see N Walker, 'Constitutional Pluralism Revisted' (2016) 22 European Law Journal 333. Amongst constitutional pluralists Walker's account is more cautious about claims to have overcome sovereignty and more insistent on presenting constitutional pluralism as a matter of political as much as legal theory. Walker's term 'late sovereignty' rather than 'post-sovereignty' illustrates this more nuanced view on the enduring legacy of the concept, see 'Late Sovereignty in the European Union' in Walker (ed.) Sovereignty in Transition (Hart Publishing, 2003).

${ }^{9}$ N MacCormick, 'The Maastricht-Urteil: Sovereignty Now' (1995) European Law Journal at 264
} 
jurisprudence, on the question of the highest guardian of fundamental rights. But rather than spill into open conflict it resulted in an uneasy truce between the ECJ and the Bundesverfassungsgerricht. ${ }^{10}$

The normative value of constitutional pluralism is cashed out in this contest. Each system should retain its authority, leaving any conflict in a state of irresolution and thereby avoiding monism and the hierarchy of either the domestic court or the ECJ. Instead of insisting on the ultimate legal authority of one or the other (or a third party), constitutional pluralists argue for a recognition of two 'equally legally valid' claims. Pluralism and heterarchy can be maintained by holding open the question of ultimate KompetenzKompeten₹, avoiding 'outright collision' through mutual deference and accommodation between courts. ${ }^{11}$

MacCormick insists that pluralism does not imply an absence of order between the two sets of legal systems. ${ }^{12}$ It is, however, premised on absence of sovereignty, ${ }^{13}$ which, like virginity, is 'lost without another's gaining it', as he memorably put it. ${ }^{14}$ This methodological move recalls Hans Kelsen's attempt to overcome the question of sovereignty by insisting on an exclusively juristic concept of the state. But MacCormick takes a different route than Kelsen and evades even the concept of the state as a symbolic representation of legal unity, substituting it for the notion of a 'Commonwealth'. Since law, for MacCormick, is institutional normative order, it does not depend on a transcendental basic norm, but a 'working constitution', a 'kind of shared custom or convention held amongst those who treat the constitution as foundational of normative order'. Looking at the practice of legal officials in both Member States and the EU, he concludes that legal superiority will depend upon which perspective one takes, which 'internal point of view', in Hart's conceptual vernacular. ${ }^{15}$ Pluralism thus refers to the plurality of perspectives one might adopt with regard to the ultimate rule of recognition in the European Commonwealth.

\section{B. CONSTItUTIONALism}

${ }^{10}$ Cf. B-O Bryde, The ECJ's Fundamental Rights Jurisprudence - A Milestone in Transnational Constitutionalism' in M. P. Maduro and L. M. Azoulai (eds.) The Past and Future of EU Law (Hart Publishing, 2010).

11 MacCormick, above note 10.

${ }^{12}$ The idea of pluralism under international law is, he concludes, 'contextually more persuasive and appropriate' (Questioning Sovereignty, above, at 121). Although if the discretion of national courts is qualified by their international obligations, there is little specification of precisely what those entail (see e.g. Questioning Sovereignty, above at 117).

${ }^{13}$ See e.g. Ouestioning Sovereignty, above, at 10.

${ }^{14}$ Note 1 above, at 16. Repeated less assertively in Questioning Sovereignty, above at 126 . In the final iteration, eschewing any form of radical pluralism, MacCormick suggests that conflicts between domestic and EU law should ultimately be determined, in Kelsenian fashion, by norms of international law.

15 Questioning Sovereignty, above, at $94-95$. Since, according the internal view of UK officials sovereignty remains with the UK constitution, but according to EC officials it lies with the Treaties, MacCormick argues that the theorist seeking a disinterested perspective 'can entertain both or several views cognitively, suspending any question of volitional commitment to one or another. Instead of committing oneself to a monocular vision dictated by sovereignty theory, one can embrace the possibility of acknowledging differences of perspective, differences of points of view', note 1 above, at 6 . 
MacCormick was equivocal on what lay behind the positive law, qua norm, institution or convention. He hinted that not all interpretative conflicts could be resolved judicially, that not 'every legal problem has a legal solution'. ${ }^{16}$ But he also proclaimed a belief that Hart's positivism 'can supply the account that is needed to make credible an approach to sovereignty as a predominantly legal concept'. ${ }^{17}$ And throughout Questioning Sovereignty, MacCormick effectively endorses the legalistic and characteristically German positivist equation of sovereignty with the issue of supreme judicial interpretative authority, the question of judicial Kompetenz-Kompeten . $^{18}$

It is by working with a legal rather than political conception of sovereignty that constitutional pluralism is able to emerge. Underneath the legal topsoil, this move is determined by Hart's critique of Austin's command theory, the stepping stone into Hart's own concept of law. As is well known, Hart rejected Austin's account because he thought its focus on command neglected a significant type of rule - power-conferring rules - and the modality of rule-based behaviour - the internal aspect of rules which distinguishes them from mere habits of obedience. ${ }^{19}$

MacCormick, like Hart, rejected Austin's conception of law as command based on habitual obedience to a political superior. But this focus gets in the way of tackling Austin's concept of sovereignty, which is entirely reductive, neglecting the process through which political power is generated and acquires legitimacy. MacCormick, like Hart, flips the issue over, targeting official legal practice and adherence to a conventional rule - a 'rule of recognition' - as foundational of a legal system. The focus on legality displaces the question of legitimacy.

As a consequence of cleaving so close to Hartian jurisprudence, MacCormick offers only a threadbare account of how political power and authority is constituted in the context of European integration. With Austin's conception of law as the target, MacCormick remains implicitly tied to the same reductive conception of political power. ${ }^{20}$

In the Chorley Lecture itself, MacCormick's concern with pursuing this jurisprudential project gets in the way of any robust constitutional analysis of the EU as a legal-political entity. This is apparent from his suggestion - even if to be dismissed - that the fact of habitual obedience of the UK to Europe, with the threat of sanction for any unilateral exit, might imply that Europe is ultimately politically sovereign. MacCormick rejects this not because it is a flawed conception of political sovereignty, but because he prefers Hart's legal conception which, he thinks, can do without the concept of sovereignty altogether, based instead on the acceptance - the internal point of view - of legal officials of a rule of recognition. Pluralism is thereby a suitable way to capture the apparent reality of radically different legal viewpoints, of the domestic official and the European official.

\footnotetext{
${ }^{16}$ Questioning Sovereignty, above, at 119

17 Italics added.

18 ibid.

${ }^{19}$ HLA Hart, The Concept of Law (Clarendon Press, 1961).

20 This, essentially, is Martin Loughlin's challenge, to which MacCormick struggles to respond. See N

MacCormick, 'Questioning Post-Sovereignty' (2004) 29 European Law Review 852
} 
The absence of any robust analysis of the relational aspect of legal-political authority is not merely an error of constitutional theory, however; it has practical repercussions. With regard to European integration it leads, for example, to an implausible normativism: MacCormick's stated belief that 'the relationships of the various parts [of the EU] will depend in the long run' not on various constellations of political power and legitimate authority but 'on a still-to-be-elaborated principle of subsidiarity.'21 The absence of a relational analysis also flattens out the relative authority of the Member State on the one hand, and the EU on the other. Presenting their claims as 'equally legally valid' ignores fundamental material asymmetries between the two sets of entities in terms of power and authority, or legality and legitimacy: in regard to the two key functions of the modern state - to determine warfare and welfare - there is simply no comparison between the Member States and the EU.22

Later pluralists took a different approach to MacCormick, not in offering a more robust conception of the political, but in offering a more expansive account of legality. ${ }^{23}$ This opens up a path to an explicitly cosmopolitan route and a substitution of sovereignty for public reason as a standard for assessing institutional arrangements and outcomes in any multilevel system. ${ }^{24}$ Other constitutional pluralists had, by then, begun to take a different tack too, offering distinct, non-legal registers to resolve conflicting authority claims: e.g. an ethics of constitutional tolerance, moral principle, dialogical consensus, institutional harmony, contra-punctual law. ${ }^{25}$ In each case, the search was for some normative order above the conflicting systems. Order depended on the ability to identify and in so doing generate a kind of universal ratio - constitutional tolerance, principles of legality, or subsidiarity. This was a period of tremendous constitutional optimism, at least in the academy, it should be recalled, constitutionalism set to 'rule the world', as one collection suggested, based on the authority of its universalist values. ${ }^{26}$ As for sovereignty, ' $[\mathrm{t}]$ he real lawyerly task is to neutralise this question', according to one commentator. ${ }^{27}$

As some astute observers have noted, this manner of reconciliation appeals to if not collapses into a different form of monism. ${ }^{28}$ It appeals to an answer that lies outside the

\footnotetext{
21 Questioning Sovereignty, above, at 95

22 See M Loughlin, 'Constitutional Pluralism: An Oxymoron?' (2014) Global Constitutionalism 9.

${ }^{23}$ Matthias Kumm moves beyond the positive law by situating constitutional pluralism in the domain of morality, suggesting 'applicable reasons of a general practical nature that are determinative for deciding the issue [of KompetenzKompetenz] one way or another', see Kumm, 'The Jurisprudence of Constitutional Conflict' (2005) 11:3 European Law Journal 262.

${ }^{24} \mathrm{M}$ Kumm, 'The Cosmopolitan Turn in Constitutionalism: On the Relationship Between Constitutionalism In and Beyond the State' in Dunoff and Trachtman (eds.) Ruling the World: Constitutionalism, International Law and Global Governance (CUP, 2012) 268-270. Following MacCormick, albeit less excusably given the rise in sovereignty claims in the intervening years, he also proposes that 'in the law of the European Union, the language of subsidiarity bas completely replaced the language of sovereignty' at 293 (italics added). Extraordinary that subsidiarity continued to exert hold of the constitutional pluralist imagination dispute the fact that its juristic career was an almost complete failure.

${ }_{25} \mathrm{M}$ Avbelj and J Komarek identify six versions, in their 'Introduction' to Constitutional Pluralism in and Beyond the European Union (Hart Publishing, 2012) 4 - 7.

${ }^{26}$ See note 24 above.

${ }^{27}$ See A Jakab, European Constitutional Language (CUP, 2016): 'our task is to avoid or prevent the question, and if someone still poses it, then we should give a "solution" that does not say anything practical for conflicts" (at 116). He goes on to suggest that the language of Staatslebre is 'redundant'.

${ }^{28}$ See e.g. A Somek, 'Monism: A Tale of the Undead' in Avbeli and Komarek (eds.) above.
} 
realm of the plurality of positive constitutional law but inside the legal-moral universe, to be given by Herculean constitutional scholars or judges. In some versions, proportionality becomes a meta-principle, offered from within the juridical discourse as a means to weigh or balance competing constitutional claims. ${ }^{29} \mathrm{But}$ in the absence of any scientific scale to measure these values, which may well conflict with one another, we are left with a set of relatively constrained - decisions, no less political simply because of their juridical dressing. If we ask what the figure of Hercules - whose decisions always represent the "true" meaning of the law - represents, do we have a better answer than "the sovereign"? 30

\section{THE POST-SOVEREIGN STATE: FACT OR FICTION?}

Does all this mean that MacCormick's 'post-sovereign' agenda is simply a juristic fiction or ideology that can be casually dismissed? The answer is both 'yes and no'. It is fiction in the straightforward sense that no legal system is self-executing, no constitution freestanding from the material order that undergirds it. ${ }^{31}$ To the extent jurists think they can transcend or neutralize sovereignty they are merely offering a new fiction, an ideology in the critical sense of the term, meaning an idea belonging to a particular social group but which purports to universality. But the ideology is not freestanding: post-sovereignty corresponds to real constitutional phenomena; it is a significant feature of the constitutional imaginary of postwar Europe. Popular sovereignty is repressed through the subsumption of constituent power into constitutional texts and judicial interpreters. Sovereignty is not transcended or neutralised but it is transformed, as evidenced by the explicit language adopted by some jurists of the 'sovereignty of the law'.32

To pursue this line of enquiry, we need to discard MacCormick's legal positivism and delve into the various layers of Europe's material constitution: the formation of polity unity in conditions of plurality, various and competing institutions and their relative strengths and weaknesses, the solidity or fragility of social relations, and the various and conflicting political objectives pursued by the European polity and its Member States. ${ }^{33} \mathrm{~A}$ full account of this would involve mapping the concrete ways in which various forms of power are materially constituted and channeled - bolstered, transformed, restrained through European law and politics.

${ }^{29}$ Cf J Bomhoff, Balancing Constitutional Rights (CUP, 2013)

${ }^{30}$ P Kahn, Political Theology: Four New Chapters on the Concept of Sovereignty (Columbia University Press, 2011) 81, he continues, 'the court's decisional authority is inseparable from its claim to speak in the voice of the sovereign people... not the moral authority of Hercules but the political authority of We the People' (ibid.).

31 See M Goldoni and M Wilkinson, 'The Material Constitution' (2018) Modern Law Review 567.

${ }^{32}$ See e.g. F Jacobs, The Sovereignty of the Law: The European Way (CUP, 2007). The new histories of legal integration present the early push for supremacy of European law as akin to a juridical coup d'état; see A Vauchez, 'The Transnational Politics of Judicialisation: Van Gend en Loos and the Making of the EU Polity' (2010) 16 European Law Journal (2010) 1; A Cohen, 'Constitutionalism without Constitution: Transnational Elites Between

Mobilisation and Legal Expertise in the Making of a Constitution For Europe (1940's-1960's)' (2007) 32 Law and Social Enquiry 109; M Rasmussen, 'The Origins of a Legal Revolution: The Early History of the European Court of Justice' (2008) 14:2 Journal of European Integration History.

${ }^{33}$ For an elaboration of these basic building blocks, see Goldoni and Wilkinson, above. 
The aim here is more modest. It is to show how the folding in of political sovereignty into legal constitutionalism is not only a figment of the juristic imagination. On the contrary, it appears to capture a material transformation in the postwar European state and state-system, a phenomenon that provides the concrete foundations for constitutional pluralism to develop. I have used the label 'authoritarian liberalism' to identify this constitutional matrix, to capture both the means - legal and technocratic as opposed to democratic - and the ends - economic liberalism and associated phenomena such as marketisation and privatisation. ${ }^{34} \mathrm{~A}$ sketch here will have to suffice.

The post-sovereign era begins with the reconstitution of Europe in the aftermath of the Second World War, in significant part as a reaction to the interwar breakdown of liberal constitutionalism, paradigmatically in West Germany. Jan-Werner Müller has documented in some detail the political-constitutional history of this transformation, using the label 'constrained democracy' and identifying Christian Democratic politics as central to its constitutional dynamic. ${ }^{35}$ It is neatly encapsulated in the story of West German postwar constitutional development: 'we are (afraid of) the people'. ${ }^{36}$ Reaction to the fear of popular sovereignty entailed a new vision not only of the governing function - in particular the new technocratic style - but of the governing relationship, the relation between state and society. It is a vision of de-democratisation both of the constituent and of the constituted powers, of sovereignty and of government.

Popular sovereignty and democratic government would be constrained both through internal and external institutional reforms and institution-building, particularly through the allocation of authority to constitutional courts and other counter-majoritarian structures. Where these guard 'unamendable' constitutional provisions they would constrain even the derived constituent power, preventing certain forms of constitutional change and even erecting substantive limits (through the principle of unamendability). In the German and Italian cases this would lead to doctrines of counter-limits, protecting, at least on paper, a constitutional core from erosion by way of supranational and international agreements. ${ }^{37}$

As a constitutional vision, the repression of sovereignty was presaged in the work of the German ordo-liberals, who had begun their work in the interwar period. As Carl Joachim Friedrich understood already in 1955, and as Foucault would later explore in his lectures on neo-liberal governmentality in 1979, the decisive theoretical turn triggered by German ordoliberalism had been to replace constituent power, qua popular sovereignty, with individual economic freedom - a freedom to participate in the market - as the legitimating device for the whole constitutional order. ${ }^{38}$

\footnotetext{
${ }^{34}$ See e.g. M Wilkinson, 'Authoritarian Liberalism in the European Constitutional Imagination: Second Time as Farce?’ (2015) European Law Journal 313.

35 See J-W Müller, Contesting Democracy: Political Ideas in 20th Century Europe (New Haven: Yale University Press, 2011).

${ }^{36}$ See C Möllers, 'We are (Afraid of) the People: Constituent Power in German Constitutional Thought', in Loughlin and Walker (eds.) The Paradox of Constitutionalism (Oxford: OUP, 2008). The UK represents a different constitutional type, along with the sustained democracies of the Nordic countries.

37 With regard to the Italian constitutional court: cf. V Barsotti, P Carozza, M Cartabia, A Simoncini, Italian Constitutional Justice in the Global Context (OUP, 2016) 214-217.

38 See CJ Friedrich, 'The Political Thought of Neo-liberalism' (1955) American Political Science Review 49, M Foucault The Birth of Biopolitics — Lectures at the College de France 1978-1979 (London: Palgrave MacMillan, 2008).
} 
For the ordo-liberals, the new economic constitutionalism, based on formal equality, individual economic rights and market competition, was intended to achieve the complete abolition of class struggle as well as national conflicts from the political domain. ${ }^{39}$ The class-conscious struggles of the inter-war period - emboldened by the arrival of mass democracy - would be repressed in order to secure political and economic stability, considered threatened by the democratic forces that had been unleashed with universal suffrage. The new civil religion for the post-war order would be fiscal prudence, efficiency and market rationality, the model of the German economic miracle. Democracy would be constrained not (only) for fear of its violating civil or political rights but out of concern for its impact on economic stability. The strong constitutional state would protect the market economy, and disarm any democratic (or capitalist) threat to it.

The logic of economic constitutionalism is developed by the European Court of Justice as it turns itself into a supranational and effectively 'constitutional court'. 40 The two processes of domestic reconstitution and European constitutionalization are partly independent - dealing initially with functionally differentiated spheres - but partly intertwined. So, for example, domestic constitutions lay down obligations towards international law and European integration; ${ }^{41}$ European Union law draws on 'common constitutional traditions' of the Member States. Outside formal routes, the compound constitutional architecture depended on a degree of mutual deference and respect. In this regard, we might see the Solange saga as the highpoint of constitutional pluralism, long before it was labeled academically as such. ${ }^{42}$

The post-sovereign condition also reflects a change in the social imaginary towards a distinct notion of the nature and limits of the democratic right to rule, including over the economy. It lays out a new vision of our social relations, of the person as a market participant (a consumer) rather than a political citizen; in the age of rights, market rationality would dominate over political rationality. ${ }^{43}$

Constrained democracy is a more accurate label to capture this phenomenon than the inappositely named 'militant democracy' with which it is sometimes associated, since the purpose of the postwar settlement was not to promote strong vibrant publics. ${ }^{44}$ On the contrary it was a tamed, deracinated constitutionalism that developed. This reflects not only that elites are afraid of the people, but that the people are afraid of themselves, captured as a psychosocial phenomenon in Eric Fromm's Escape From Freedom. 45

${ }^{39}$ See Bonn, Ludwig-Erhard-Stiftung, Standard Texts on Social Market Economy: Two Centuries of Discussion, Horst Friedrich Wunsche ed. Derek Rutter trans. (Stuttgart: Gustav Fischer Verlag, 1982) ix. This reverses the original meaning of the economic constitution, which had meant democratic control of the economy and emancipation of the working class (in the work of Neumann and Sinzheimer). See e.g. R Dukes, The Labour Constitution: The Enduring Idea of Labour Law (OUP, 2014).

${ }^{40}$ See e.g. M Maduro, We the Court: The European Court of Justice and the Economic Constitution (Hart Publishing, 1998).

${ }^{41}$ For discussion, see B De Witte, “The European Union as an International Legal Experiment' in De Burca and Weiler (eds.) The Worlds of European Constitutionalism (CUP, 2012), 19 - 57.

${ }^{42}$ See e.g. B-O Bryde, above.

${ }^{43}$ See e.g. W Streek, 'Citizens as Customers: Considerations on the New Politics of Consumption' (2012) New Left Review 27

${ }^{44}$ See Müller, above.

${ }^{45}$ Authoritarianism here thus points towards a politically passive population in contrast to a highly charged, active movement. 
The folding in, or repression of sovereignty that begins with postwar reconstruction is not therefore merely a rhetorical move advanced by jurists; it has political and social content. ${ }^{46}$ It reflects the identity of a society that has lost faith in its ability to exert political control, anchoring itself instead in the realm of self-prescribed ethical and legal principle, and the elite-led governance of experts. ${ }^{47}$ Juridical constitutionalism is underwritten by this more fundamental social change, relating to the idea and practice of collective selfgovernment and its limits. Politics is moderated, eventually narrowed to an extreme centre. This is a phenomenon that applies to the sovereign state itself, if often pursued through and reinforced by EU membership. ${ }^{48}$ It should be viewed neither as a purely domestic project transported to the EU, nor as a supranational experiment that is domesticated. It is a transformative development involving both simultaneously. ${ }^{49}$

The phenomenon of increasingly apolitical or technocratic governance has been captured in political economy and critical sociology as a feature of the neoliberal period of 'post-politics' or 'post-democracy'. ${ }^{50}$ This is described as a key constitutional feature of the neo-liberalisation of government of the past few decades, a process which has 'depoliticised' or 'de-democratised' significant areas of policy and law-making, extended dramatically through the creation of Economic and Monetary Union at Mastricht. It tracks a similar transformation as captured here under the label post-sovereignty. But the term neoliberal must not occlude that the ground for this transformation is laid much earlier than usually implied by the term neoliberal - beginning from the start of postwar reconstruction - and that de-democratisation goes not only to the governing process but to the state and the concept of sovereignty itself.

\footnotetext{
46 This is carefully noted and outlined by N Gibbs, 'Post-Sovereignty and the European Legal Space' (2017) Modern Law Review 825.

47 Gibbs, ibid., drawing on Marcel Gauchet.

${ }^{48}$ See e.g. S Hix and A Follesdal, 'Why there is a Democratic Deficit in the EU: A Reply to Majone and

Moravscik' (2006) Journal of Common Market Studies 533.

${ }^{49}$ See especially C Bickerton, European Integration: From Nation-States to Member States (OUP, 2012).

${ }^{50}$ See e.g. C Crouch, Post-Democracy (Polity Press, 2004).
} 
IV. THE ROAD FROM MAASTRICHT: BEYOND THE POSTSOVEREIGN STATE?

The ideal-type of 'post-sovereign constitutionalism' sketched above does not resonate to the same extent in each domestic constitutional context. ${ }^{51}$ But it is not merely one idealtype amongst others, it is also a dominant type, particularly when viewed in combination with a project of European integration made in its own image, as typified in the narrative of 'integration-through-law'. 52 This is the ground on which constitutional pluralism is constructed, as authority is increasingly constitutionalized, protected by counter-majoritarian institutions, especially constitutional courts, and pluralised, exercised by institutions at national and supranational level, often as features of the same quasi-federal constitutional architecture.

But, contrary to MacCormick's supposition, Maastricht did not signify the moment of transition towards this post-sovereign condition. That transformation in the constitutional imagination had already taken place. Maastricht signified, on the contrary, that the era of the 'post-sovereign state' was reaching a turning point. In other words, the ground that had been laid for constitutional pluralism, far from being fortified at Maastricht, appears increasingly unstable, as sovereignty claims begin to make their return after a hiatus of half a century. Political sovereignty, having been folded into legal constitutionalism, begins to spring back into action. ${ }^{53}$

The return of sovereignty is often associated with the increasingly hostile rhetoric of the German Constitutional Court towards the project of integration and the authority of the ECJ. ${ }^{54}$ MacCormick himself offered a qualified defence of the German Constitutional Court, its Maastricht decision having 'a sound basis in legal theory', 55 if politically misguided. He rejects its assertation of any 'continuing sovereignty of the German people', 56 and concludes with an emphatic denial that sovereignty 'is a continuing property of any Member State' other than in the residual and formal sense that each is able to revoke

\footnotetext{
51 There are at least three others: the sustained democracies, the Mediterranean Enlargements, and the Post-Soviet accessions. It is with the deepening and widening of the Maastricht era that the broader constitutional context starts to matter; in these four 'varieties of constitutionalism' sovereignty and hence post-sovereignty resonate differently. Post-sovereignty in the manner described above did not reflect in the same way the sustained democracies of the UK and Scandinavia, nor for the Mediterranean Enlargements. And for obvious historical reasons, fears of democratic and state sovereignty so central to the German postwar experience, and to those countries with direct experience of Fascism, would not resonate in countries transitioning from the Soviet bloc: their constitutional consciousness was characterised by a fear not of internal democratic collapse, but of externally repressed sovereignty under the Soviet regime.

52 See Vauchez, Cohen, Rassmussen, above.

$53 \mathrm{On}$ the significance of sovereignty claims and sovereignty frames to the concept of sovereignty, see $\mathrm{N}$ Walker,

'Sovereignty Frames and Sovereignty Claims' in Rawlings, Leyland, Young (eds.) Sovereignty and the Law: Domestic, European and International Perspectives (OUP, 2013).

${ }^{54}$ Constitutional pluralism has an ambiguous relationship with the German Constitutional Court in general and its Maastricht-Urteil in particular. The significance of that judgment for generating the momentum for constitutional pluralist scholarship can hardly be doubted. But constitutional pluralism appears a defensive rear-guard reaction to its judgments, a series of attempts to domesticate them, to temper their potentially harmful effects on the European constitutionalist project and the post-sovereign condition.

55 See MacCormick, note 10 above, and Questioning Sovereignty, above at 265.

${ }^{56}$ Ibid.
} 
membership of the EU. But even that right exists only on paper, and he adds, politically, it is doubtful any could 'effectively' leave the EU 'in present circumstances'. ${ }^{57}$

Legally sound, politically dubious. 'Post-sovereign' the judgment most certainly was not, as the court clearly asserts the constitutional sovereignty of the German basic law and its own interpretative Kompeten $2-K o m p e t e n \approx$. With its strident assertions of domestic constitutional sovereignty; the Member States as the 'Masters of the Treaty'; and its insistence on the constitutional significance of the democratic deficit of the EU prefiguring the voluminous literature on the so called 'no demos' thesis - the MaastrichtUrteil already offered a serious challenge to the idea and practice of post-sovereignty that had developed in the postwar period.

The full implications of the judgment would be spelled out more explicitly in the later Lisbon Treaty decision: sovereignty qua constitutional identity - including democratic discourse over 'essential state tasks' - is inviolable, even if the Court, again, ultimately accepted the constitutionality of the European Treaty. ${ }^{58}$ As Christoph Schonberger puts it, there is no judgment in the history of the Karlsruhe court where the conclusion - the constitutional permissibility of ratification of the Lisbon Treaty - is so much at odds with the reasoning: an emphatic assertion of national constitutional sovereignty. ${ }^{59}$

The Lisbon ruling also gave the doctrine of restrained democracy a new twist: sovereignty could not be upscaled to the European Union to create a fully democratic panEuropean federal state. To do so would violate the eternally guaranteed provisions of the German Basic Law designed to protect democracy itself. What had been left open at Maastricht - the gradual development of a European demos - was now closed.

To be sure, the challenge to post-sovereignty represented by the Maastricht era is complex and uneven. The discourse of sovereignty returns, but not in the guise of a straightforward proclamation of the democratic constituent power or the wholesale rejection of the technocratic organs of governing and domestic and external constraints that had evolved in the postwar period. On the contrary, technocracy deepens, depoliticisation and de-democratisation continue apace, most acutely with the plans for EMU in respect of the monetary authority of the Member States of the single currency. The unevenness and uneasiness of the discourse on sovereignty is evident from the German debate itself - assertive if largely unconsequential in the Maastricht ruling and evasive with regard to the question of constituent power in a newly reunified and sovereign country after the fall of the Berlin Wall. 00

Sovereignty claims start to resurface across formal and informal channels as various irritants. They return not predominantly via a revitalized public sphere or democratic social movements but via constitutionalist challenges; through constitutional identity politics; and most obviously perhaps, the revival of various nationalisms. ${ }^{61}$ With the space for

\footnotetext{
57 Questioning Sovereignty, at 265.

58 BVerfGE, 123/267 Judgment of 30 June 2009.

${ }^{59}$ C Schönberger, 'Lisbon in Karslruhe: Maastricht's Epigones at Sea' (2009) 10 German Law Journal, 1201-1218. ${ }^{60}$ See S Chambers, 'Democracy, Popular Sovereignty, and Constitutional Legitimacy' (2004) 11 Constellations 153173.

${ }^{61}$ See J Heartfield, 'A Process without a subject' in Bickerton, Cunliffe and Gourevitch (eds.) Politics without Sovereignty (Routledge, 2006).
} 
democratic sovereignty having been largely vacated, politics hollowed out, it is identity that fills the gap, whether constitutional, cultural, or consumption-oriented. Constitutionalism, rather than 'ruling the world', appears to have been ruling only a 'void'. ${ }^{62}$

These irritants gather pace throughout the Euro-crisis, and approach a climax with a series of events that highlight the return of sovereignty claims: the election of Syriza in Greece on an anti-austerity platform, the direct challenge of the German Constitutional Court to a programme of the European Central Bank credited with saving the Euro, a migrant crisis which sees the collapse of the Schengen and Dublin regimes, the triggering of Article 50 for the first time as a Member State prepares to leave the EU, and a rule of law crisis in respect of countries violating the foundational values of the EU. ${ }^{63}$

The crisis of post-sovereignty is complex due to the fact that there are now different sets of sovereign claims exerting pressure on the current system. Sovereignty claims reemerge both 'from below' - in regard to the so-called 'populist' surge in the nation-state, in the core of Europe as well as in the periphery - and 'from above', in regard to a European Union that is increasingly exercising emergency politics of its own. The centrifugal force of resurgent nationalisms is thus matched by the centripetal force of a 'sovereignty-to-come', exerted through formal institutions such as the European Central Bank (in turn bolstered by European Court of Justice), 'formally informal institutions' such as the Euro-group, and informal efforts at consolidating the EU's authority such as Juncker's 2018 'State of the Union address', dramatically entitled 'the hour of European sovereignty'.

But the sovereign claims of Member States on the one hand and the ECJ, the ECB and the Commission on the other, represent a picture of highly distorted notions of sovereignty, based on a mix of nationalism, technocratic authority and German mercantilist interests. ${ }^{64}$ Some states are clearly more post-sovereign than others. ${ }^{65} \mathrm{Without}$ a genuine sense of member state equality, the federation is liable to shade into a hegemonic entity, dominated by a single state, or a bloc of states, and even to evoke imperialism in its political form.

62 See P Mair, Ruling the Void: The Hollowing Out of Western Democracy (Verso, 2013).

${ }^{63}$ See M Wilkinson, 'Constitutional Pluralism: Chronicle of a Death Foretold?' (2017) European Law Journal (2017) 213.

${ }^{64}$ See eg C Lapavitsas and H Flassbeck, Against the Troika: Crisis and Austerity in the Eurozone (Verso, 2015). ${ }^{65}$ See M Wilkinson, "The Euro is Irreversible! Or is it? On OMT, Austerity and the Threat of "Grexit"' (2015) German Law Journal 1049. 


\section{DEMOCRACY, POPULAR SOVEREIGNTY AND POLITICAL ECONOMY: CONSTITUTIONAL PLURALISM'S MISSING MATERIAL}

As Jürgen Habermas had argued after the Maastricht-Urteil, the democratic deficit of the EU was already 'expanding day by day because the economic and social dynamics even within the existing institutional framework perpetuate the erosion of national powers through European law'. ${ }^{66}$ After Maastricht, questions of the compatibility of European Union with political sovereignty and democracy begin to take political centre stage in a way that they had not previously.

These democratic and political-economic aspects of constitutional transformation were almost entirely missed by MacCormick. In Questioning Sovereignty, despite its focus on the European Union, one looks in vain for any discussion of the impact of market integration on social values, or the likely impact of the single currency on macroeconomic policy choices. ${ }^{67}$ So, for example, although he integrates 'neoliberal market subsidiarity' into his complex and abstract constitutional formula for the 'European commonwealth', he entirely evades the concrete effects of market integration as it has in practice shaped the political economy of the EU, including in large part as a result of decisions of the European Court of Justice. ${ }^{68}$

Questions of political economy in general and economic constitutionalism in particular hardly feature at all in MacCormick's analysis and it is worth pausing briefly to consider why. It is not because the discussion remains 'pure' in a Kelsenian sense. The key non-legal phenomenon around which the legal discussion of sovereignty and postsovereignty is constructed is nationalism. ${ }^{99}$ MacCormick's more specific goal is to defend nationalism, at least a moderate civic variety, a 'liberal nationalism', whilst attacking the notion of sovereignty as both outdated and undesirable. But where does nationalism without sovereignty leave democracy, other than as a vague cultural connection, or indeterminate appeal to subsidiarity?

MacCormick explicitly defended a 'mixed constitution' or 'mixed commonwealth' rather than a democratic constitution. ${ }^{70}$ This is also how he saw the European Union developing. The concrete weakness of the position lies in the implicit assumption that social democracy could be protected through such a 'mixed constitution', where the elements held in balance are 'oligo-bureaucratic' and only 'indirectly democratic'. ${ }^{71}$ In these passages he briefly alludes to the - already apparent - democratic deficit of the EU but clearly wants to minimize it as a political and constitutional issue.

\footnotetext{
${ }^{66}$ J Habermas, 'Remarks on Dieter Grimm's 'Does Europe Need a Constitution” (1995) 1 European Law Journal, 303.

${ }^{67}$ MacCormick's declared political goal was to pursue a soft version of social democracy. He firmly rejected any 'purely market-economical view of the good society' (Questioning Sovereignty, 174-5). As a matter of political philosophy, he explicitly attacked voluntaristic liberalism of the social contract variety in favour of contextual individualism associated with the communitarian tradition (e.g. ibid. at 162-3).

${ }^{68}$ Ouestioning Sovereignty, 152. Elusively, and all too briefly, he skirts over 'whatever storm clouds now hover over the prospects for the single currency', 155. MacCormick was far from the only one to succumb to what Majone later characterized as the 'culture of total optimism'.

${ }^{69}$ See chapter 11 of Questioning Sovereignty.

${ }^{70}$ Ibid. 145 - 149 .

${ }^{71}$ Ibid., at 149 .
} 
This neglect is underwitten by MacCormick's point of departure. The Austinian framework of sovereignty as political command elides sovereignty as a symbol of collective self-determination, of the relative autonomy of the political in a secular and democratic state. Modern democratic sovereignty assumes the autonomy of the political vis-à-vis both the church and the market as it were. To move beyond sovereignty is not, or not merely, to leave command theory behind; it is to risk surrendering democracy to new theologies or market rationality.

Constitutional pluralists show little recognition of this, even once neo-liberalism and ordo-liberalism have become a significant part of the academic vernacular and critical theorizing has become more mainstreamed into EU studies. ${ }^{72}$ How varieties of social democracy, or 'varieties of capitalism', can withstand the dynamic of market integration is a question they rarely posed, although clearly central to any concern for protecting constitutional plurality.

The failure of the Constitutional Treaty in 2005 began to reveal cracks in the legitimacy of the project of integration that in reality had begun to open up since Maastricht. The cracks became more serious after Viking and Laval, once it was more widely observed that because of the logic of the single market in combination with the principles of supremacy and direct effect of EU law, European constitutionalism in practice was operating in favour of free movement of the factors of production and to the detriment of fundamental rights, especially social rights and welfare entitlements. ${ }^{73}$

Constitutional pluralists could have objected to these developments, on the grounds that prioritising economic freedoms in EU law was in danger of eroding values and concrete relationships protected within the domestic constitutional order. The two systems (domestic and European) may have been 'equally valid' in theory, but this did not reflect the practical impact of their collision and coexistence. The legitimate concern would have been that the primacy of EU law in conjunction with an expansive interpretation of free movement would potentially negate any parity of norms between domestic and European constitutions, eroding the heterogeneity in political economy. But constitutional pluralists tended to avoid the material flashpoints, seeking reconciliation rather than rebellion. To link the discussion back to MacCormick's earlier emphasis on social democracy, due to the trajectory of integration and its political-economic asymmetries structured through the constitutionalising of free movement, even retaining an equilibrium between democracy and capitalism would in practice have required strong defence of the domestic welfare state and domestic democratic autonomy. ${ }^{74}$ Fritz Scharpf saw this clearly and explained the structural reasons for the neoliberal bias in the EU's economic constitution in painstaking detail..$^{75}$

Constitutional pluralists were not card-carrying neoliberals, although, to be sure, few neoliberals carry their membership card openly. But their neglect of the material

\footnotetext{
${ }^{72}$ See especially F Scharpf, 'The Asymmetry of European Integration: or Why Europe Can't Have a Social Market Economy' (2010) 8 Socio-Economic Review 211 - 250

${ }^{73}$ See e.g. M Lasser, 'Fundamentally Flawed' (2014) 15 Theoretical Inquiries into Law 229.

${ }^{74}$ See e.g. W Streeck, Buying Time: Reflections on the Delayed Crisis of Democratic Capitalism (Verso, 2014).

${ }^{75}$ See e.g. Scharpf, above. In fact, as Scharpf explains, it was already grasped by Hayek in the 1930's in his work

on interstate federation.
} 
consequences of integration along with a certain European constitutional optimism and anti-statist bias obscured the path being taken. The cases of Viking and Laval, although indicative of the neoliberal trajectory of integration, would pale in comparison to the scale and extent of the demands of structural adjustment that would be made within the Euroregime on debtor states. But it is important to note that, materially, the Euro-crisis response represents a deepening rather than departure from the economically liberal path of integration that had accompanied the post-sovereign condition: marketisation, privatisation and liberalisation are accelerated, if under the auspices of an austerity regime accompanied by the rhetoric of exceptional politics and economic emergency.

\section{CONCLUSION}

The states of Europe are one set of entities, the European Union another, announced MacCormick in 'Beyond the Sovereign State'. ${ }^{76}$ The notion that the states of Europe are 'one set' of entities may be trivially true in so far as each of them are (not-fully-sovereign) states. But in its generality it obscures what is significant about their constitutional authority, not only their diverse constitutional histories, and their diverse relationships with the EU and the project of integration, but their varying power and authority within and across the EU. This not only reflects informal hierarchy between debtor and creditor states and between surplus and deficit countries, it also now has a material impact through formal institutions such as the European Stability Mechanism and the European Central Bank.

This raises a concluding point, which is that plurality itself was strangely absent from the constitutional pluralist literature. In focusing its analytical and normative energies almost entirely on the relationship between the domestic and European constitutional orders - mirrored in the anti-pluralism that now seeks to bury it - constitutional pluralism neglected a crucial relationship: the horizontal relations among Member States.

A significance part of the purpose of the project of European integration was always to promote restrained sovereignty not vis-à-vis a notional supranational entity, but vis-àvis other states. Supranationalism was the means towards the end of balancing the powers of Europe, not an end in itself. This goal was initially geared towards West Germany raising the so-called 'German question' - a country whose status was anyway provisional in the post-war era due to the divisions of the Cold War. The German question would return in the Maastricht era, and has increased in significance since the Euro-crisis as hegemony is back on the agenda. ${ }^{77}$

Ironically, therefore, the anti-pluralists may have revealed an uncomfortable but significant truth. Given where the EU now is and where it is going, the only way to maintain constitutional plurality may be outside the EU as currently configured. Far from moving beyond the sovereign state, or into a post-Westphalian era, it is through

${ }^{76}$ Note 1 , above.

${ }^{77}$ Cf. U Beck, A German Europe (Polity, 2013). 
democratic sovereignty and democratic social and political movements that constitutional plurality might be resurrected. This may now depend on the possibility of rupture with the existing order; it would also require a certain level of international solidarity to work in practice, if not degenerating into an anarcho-style regional competitive disorder. But solidarity is currently substituted in the EU by a number of logics that remain in a fragile condition, fomenting increasing disequilibrium albeit without rupture: German hegemony, peripheral weakness of will and lack of alternatives to the current European economic project. None of these on its own perhaps is conclusive, but in conjunction they may signal the end of constitutional plurality.

It would be tempting now to repeat MacCormick's error and confidently proclaim that we are, already, beyond the post-sovereign state. The current situation however is too fluid, it is too early to tell where things will lead. That the accelerated return of sovereignty claims presents severe challenges to the continued relevance of the post-sovereign condition so central to constitutional pluralism seems undeniable. But whereas in the postwar settlement constitutional plurality was served by the repression of sovereignty, in the present conjuncture, plurality appears to require a renewal of democratic sovereignty. It requires the harnessing of precisely that which constitutional pluralism professed to have superseded. Moving beyond the post-sovereign state may now be the only way for constitutional pluralism to survive. Brexit then might appear as an overdue reawakening of the sleeping sovereign, and even an opportunity to reconnect sovereignty with ultimate democratic authority. ${ }^{78}$

78 On the image of the sleeping sovereign see R Tuck, The Sleeping Sovereign: The Invention of Modern Democracy (CUP, 2016) 